УДК 930.1/25(477.4)»19»:745/9

DOI: 10.31470/2518-7600-2019-8-298-319

\author{
UNKNOWN WORK OF THE 1920s ON \\ HISTORIOGRAPHY OF PYSANKARSTVO
}

\title{
НЕВІДОМА ПРАЦЯ 20-Х РОКІВ ХХ СТОЛІТТЯ 3 ІСТОРІОГРАФІЇ ПИСАНКАРСТВА
}

\section{НЕИЗВЕСТНЫЙ ТРУД 20-Х ГОДОВ ХХ ВЕКА С ИСТОРИОГРАФИИ ПИСАНКАРСТВА}

\section{Віктор Ткаченко,}

кандидат історичних наук, старший науковий співробітник, провідний науковий співробітник viktor69tkachenko@ukr.net https://orcid.org/0000-00016741-3430

Національний історикоетнографічний заповідник «Переяслав»

вул. Шевченка, 8, м. Переяслав, Київська обл., Україна, 08400
Viktor Tkachenko,

Candidate of Historical

Sciences, Senior Research

Fellow, Leading Research

Fellow

viktor69tkachenko@ukr.net https://orcid.org/0000-00016741-3430

National Historical and Ethnographic Reserve «Pereyaslav» Str. Schevchenko, 8, Pereiaslav, Kyiv region, Ukraine, 08400

\section{ABSTRACT}

The author publishes materials on the historiography of Ukrainian pysankas of the end of XIX - 20s of the XX century prepared by $S$. Shamraiev. The researcher tries to analyze the most famous editions of M. Sumtsov, S. Kulzhynsky, M. Korduba, V. Yastriebov, M. Valuiko, I. Benkovska, R. Tirelova and others, published in Ukraine and abroad. At the beginning of his work, the author notes that before the 1920s, the literature on pysanka was found to consist of small notes that mention the existence of pysankas and the need to study them. To examine them, he used the "chronologically bibliographic method» in combination with an 
attempt to show how different researchers of pysankas approached the coverage of this or that issue.

$S$. Shamraiev started his research of literature from the authors who covered the origins of the pysankas; he points out that there are two relationships between them: the first one is more scientifically proven and is related to the pagan cult of eggs, the second one is used with Christianity symbolism in their interests.

The author also considered the issue of making pysankas, when it was done, at what time, what tools and dyes were used, which decoration technologies exist, etc.

He did not ignore the question of the researchers' coverage of the ornamentation of pysankas, their origin, including the classification, mentioning the suggested researches on this issue by Wenkel, Sumtsov, Korduba, Kulzhinsky and other scientists. Noting that, in general, all studies can be divided into three areas.

The purpose of the article is to publish an archival source and familiarize the general public of scientists with it.

In the course of the work the author has used the methods of search, systematization and analysis of the obtained data.

Processing of the Scientific Archive of the Institute of Archaeology of the National Academy of Sciences of Ukraine and other sources allowed the author to state that the problems of historiography of pysankas were studied by different researchers in the 20s of the XX century, is quite diverse and requires proper study and introduction into the scientific circulation.

Key words: S. Shamraiev, pysanka, archive, sources, historiography of study.

Постановка проблеми. Для будь-яких досліджень важливим є використання архівних джерел. Серед них чимало відомих, а також неопублікованих. Значна джерельна база, щодо дослідження історіографії писанкарства наявна також у Науковому архіві Інституту археології НАН України.

Аналіз останніх досліджень. Автором статті у 2013-2018 роках вже опубліковано розвідки Н. Дмитрука , В. Кравченка, I. Шулікова, Т. Мишківської та інші, про писанкарство 3 Архівних наукових фондів рукописів та фонозаписів ІМФЕ ім. М. Т. Рильського НАН України. 
Метою статті $є$ публікація архівного першоджерела та ознайомлення із ним широкого загалу науковців.

Основним завданням автор вбачає виявлення нових архівних джерел, з’ясування їх інформаційного потенціалу та введення до наукового обігу.

Відповідно до сучасної практики наукового видання першоджерел збережено особливості письма.

$* * * * * * *$

\section{Огляд літератури про писанку}

Література про писанку досить бідна, як на Україні, так і в иньших краях. Головним чином, складається вона з невеликих заміток,я кі згадують про існування писанок та відзначають потребу їх дослідження. Але, на жаль, більшість авторів підкреслюючи дуже важне значіння вивчення звичая виготовляти писанки та дослідження їх орнамента самі цілком не дбають про те, щоби перевести свої дезідерати в життя. Тому вся, дійсно наукова, література про писанку зводиться, de fakto, до невеликої кількости праць.

В свойому огляді літератури про писанку ми не будемо додержуватися методу хронологично-біографичного, а спробуємо освітлити їі по питанням, що в ній намічаються, освітлюючи як підходять до цих питаннь той, чи инший автор. При такій сістемі, ми думаємо, виклад дасть краще уявлення про стан літератури по цьому питанню та уникне, до певної міри, сухости та одноманітности.

\section{1) Походження звичая виготовляти писанки}

Більшість авторів погоджується на тому, що яйце відогравало важну ролю в культах арійських народів вже в найдавніші часи, часи поганські. Воно являлося, як каже Кульжинський, «сімволом переходу від небуття до буття; воно є сімволом життя, радощів і сонця, особливо сонця весняного, яке несе 3 собою і життя, і радість, і тепло, і світло, i відродження природи, життя якої було зковано морозом, льодом i снігом, як життя пташенят зковано яєчною скорлупою». (Описание коллекции народн. писанок, а. 33). Цеїж думки тримається і другий найвидатніший дослідував проф. Сумцов, який вважає яйце сімволом сонця, що панує в культах поганських народів. Його вшанування базується на аналогії 3 
весняним відродженням сонця, а разом з ним цілої творчої сили природи. Того-ж погляду i відомий чеський вчений Fr. Strańecek, який зазначає це в своїй статті про символіку писанки в збірнику «Moravske ornaments», також багато иньших дослідників (Валуйко, Тірелов та инш.). Докази цього культу ми знаходимо в змісті ріжних казок та лєгенд про ролю яйця (напр., про утворення світу). Богато з цих казок, що заховалися у богатьох народів, наведено 3 Сумцова, Кульжинського та инш. В зв'язку з шануванням яйця стоїть шанування і курки та півня, а разом з тим, до певної міри і иньших птахів. На це докладно вказують Кульжинський, Сумцов, Странічек та инш. Автори. Півень (по Кульжинському), у віруваннях словян, являється зооморфичним образом сонця. На це вказує, між иньшим, і те, що як сонце збуджує ранком все від сну, так і півень своїм криком збуджує ранком людей.

Свято шанування яйця відбувалося завжди весною, коли пробуджується природа, з'являється весняне сонце та таке иньше. Святкувалося воно в день нового року, що починався ранійше у багатьох народів з весни. Так починався він колись $і$ у нас на Україні, а також во Франції (до 1556 р. з Великодня), в Англії (до 1752 р. $з 26$ березоля), в Персії ( вдень Весняного Рівноденствія) та инш. (Кульжинський ст. 45, д-р Вейссенберг та инш.).

У нас, в славянських країнах, звичай виготовляти писанки появився дуже рано. Це підкреслюють багато письменників, а в більш ранні історичні часи ми знаходимо вказівки на існування цього звичая в пам'ятках археології та в джерелах нашої історії. Так у 80 роках XIX ст. т. Уваровим при розкопці Кривушанської могили було знайдено глиняні яйця. Теж було знайдено і Хвойком в 1908 р. при розкопках на Полтавщині. В джерелах ми маємо також згадки про писанки. Так, напр., Глогер в т. I «Вісли» за 1891 р. (ст. 166) каже, що Кадлубек, польський хроніст XIII ст., в своїй праці правдоподібно (Monumentum Polonica historica) згадує про цей звичай. Далі, про цей звичай каже і Боплан (XVII ст.) в свойому описі України. В Росії ми маємо згадку, що цар Олексій Михайлович (XVII ст.) замовляв в «Оружейній палаті» виготовляти писанки. 
Є така звістка, яку наводить Кульжинський, що у Франції за часів Людовика XV-го (XVIII ст.) існував цей звичай.

Про заведення цього звичая в Свропі в літературі про писнку маються два погляди. Оден з них, найбільш науково обгрунтований, відносить появлення цього звичая ще до старих, поганських часів, зв'язуючи його з поганським культом яйця. Другий погляд, науково мало оброблений, що появився давно, розв'язує це питання в иншому напрямку. Вже в 1690 р. німецький дослідник Кобер писав в своїй «Dissertatio de oro paschali», що писанки з'явилися з часів хрестіянства. Тої-ж думкитримався і Краскій (в 1705 р.), а пізнійше Ердман і також Снсен (1706 р.), який запевняв, що крашанки сімволізують кров, проляту Ісусом за людський рід. 3 пізнійших дослідувачів тримаються подібної думки, оскільки можна зробити цей висновок з огляду змісту їх праць («Hasvéti Tojások» i «Das Ausland»), який наведений у Кульжинського (бо самі праці ми, на жаль, дістати не могли), мад’ярський вчений Viktor Molnar, а також його наслідувач dr. Schvicker.

Це твердження являється, безперечно, безпідставним, що доведено цілим рядом дослідників: Мепа, Вундерліхом, Тіреловим, Странечком, Кольбе, Венгреженовським, Валуйком, Сумцовим, Кульжинським. Зокрема останній автор висловлює цікаву думку, щодо заведення писанки на Україні; цю думку, власно кажучи, можна визнати правильною і для иньших країн. Коли почали заводити хрестіянство на Україні, то місіонеи відразу наштовхнулися на певний, вже вироблений культ, 3 яким їм довелося боротися. Як відомо, духовенство взагалі не любить одвертої боротьби, воно воліло-б зробити все тихо, непомітно, так, щоби маси навіть несчулися, що 3 ними роблять, аж поки справа не буде закінченою. До речи, всі одверті-ж заходи духовенства зустрічали завжди великий опір якраз з боку масс (згадаємо, хоч-би запровадження унії на Україні). Це добре розуміли місіонери, які заводили хрестіянство на Україні в Х-у віці. Вони намагалися ввести поки-що основу самого хрестіянства і викоренити лише ті звичаї поганства, які різко суперечили догматам хрестіянської релігії. Звичаї-ж, що не являлися ворожими цим догматам, вони залишали, пристосовуючи їх до ріжних хрестіянських свят. 
Можливо з часом, коли хрестіянство міцно закріпилося на Україні, вони бажали-б знищити ці поганські звичаї, але вже булла несила. Згадаємо, хоча-би, Івана Купала та инші обрядові звичаї, що залишилися від поганства, проти яких потім так кричали духовні владики. Теж-саме сталося і з культом яйця. Він був приурочений до Великодня, з яким совпадало це свято цього культу, як по часу, так і по подібности, і заховався до наших часів. Подібне явище ми зустрічаємо i по инших країнах, де ще ранійше було пристосовано це свято до Великодня, але пізніше духовенству (як зазначає за Болсуновським Валуйко) вдалося знищити цего звичая. Про давність заведення його в хрестіянстві пише Кульжинський, який дає кілька фактів. Так, в рукопису Х в., що заховався в монастирі Св. Анастасії коло Фесалонік, $є$ згадка про роздавання писанок на Великдень, при чому зазначено, шо ведеится це ще з часів апостольських. Що це правдиво, свідчать звичаї виготовляти писанки у яковітів, вірмен, маронітів та инш., що відділилися від єдиної церкви ще в V-VI віках. Стверджує це також факт (наведений у Валуйка), що в трунах Бальбіни-діви та Теодори мучениці були знайдені писанки.

Пристосувавши цей звичай до хрестіянських свят, Церква, щоби його виправдати, мусіла придумати пояснення його походження. Ці пояснення, легенди, про походження звичая виготовляти писанки наведені у Сумцова, Кульжинського та инш. Авторів. Головною 3 них являється легенда про заведення цього звичая Марією-Магдаліною, яка має кілька варіантів. Крім того мається багато иньших варіантів. Крім того мається багато иньших легенд записаних у багатьох дослідників (напр. Драгоманова, Чубинського та инш.).

Підводючи підсумки про походження звичая виготовляти писанки, Кульжинський приходить до таких висновків:

1. Писанки походять від однокольорових крашанок (їх оздоблення орнаментом було викликано бажанням ще більшої прикраси). Ці останні є основою стародавнього поганського звичая - свята в честь весняного відродження природи i виновника його - благодатного сонця. 
2. Звичай цей, як і багато иньших, не був знищений проповідниками хрестіянства, бо з цим звичаєм нарід занадто глибоко зрісся; але він був внесений в число хрестіянських звичаїв, йому був наданий церковно-хрестіянський зміст та сімволіка i, як так такий, він продовжує існувати і зараз.

3. Але під церквоно-хрестіянською сімволікою в писанках ховається більш давняя, поганська, сіммволіка, яка пояснює $\mathrm{i}$ зтверджує пакт перших наших висновків (Кульжин. Опис. кол. народ. писанок).

\section{Сучасний звичай виготовляти писанки}

Як показують більшість дослідувачів, звичай виготовляти писанки в сучасну нам добу заховався головним чином у словян. Тут ми бачим цей звичай найбільш розповсюдженим i найбільш живучим, доказом чого є, напр., факт виготовлення писанок в країні Вендів, з племен сорбів (коло Берліну), оточених зі всіх боків німцями i в значній мірі знаціоналізованих. Окрім всіх словян заховали ще цей звичай молдавани, греки, румуни, мад'яри, перси-шиїти, а також, до певної міри, німці та французи. На підставі широкого розповсюдження цього звичая у словян, Кульжинський робить висновок, що він (звичай) є для них питомим, а решта народів його запозичило у слов'ян. За це твердження говоре той факт, що серед иньших народів цей звичай зустрічається головним чиномякраз у сусідів словян.

Щодо орнаментації та барв писанок в залежностивід їх географичного розповсюдження, то, на жаль, це питання дуже мало освітлено. Зі всіх дослідників лише один, здається, Тадеуш Довгірд в своїй праці «Писанки» звернув на це увагу, та й то побіжно. Він висуває гіпотезу, що на півдні писанки зустрічаються найбільш яркого кольору, але 3 найбільш примитивним орнаментом. Далі, посуваючися на північ кольор починає ставати більш темним та невиразним, але за те орнаментація набуває більшої краси та складного змісту. Найбільшого-ж розвитку орнаментація набуває на півночі, але кольор там панує майже виключно темний.

На жаль цім питанням окрім Довгірда ніхто не займався і ми не маємо більших дослідів. 
Перейдемо тепер до питання самого виготовлення писанки. Перш за все подивимося, оскілки наша література дає відомостей про те, коли вони (писанки) виготовляються. Це питання освітлено досить добре лише для України. Про решту країн данних мало. На підставі повідомлень з місць дослідники приходять до висновку, що найчастіше на Україні (а також і в Чехії - Кульжинський), а, до певної міри, і в иньших країнах (напр., в Малій Азії - Сумцов) писанки пишуться в Чистий Четвер. Він це пояснює пережитком поганства, а саме: Четвер (Donnerstag) був від давна присвячений богам грому i блискавки (себ-то весняним богам) - у українців Перуну, у германців Тору та Донару. Таким .....виготовлення писанок присвячених весні в давні часи починалося якраз в цей день присвячений грозам, якими починається весна (Кульжинський).

Окрім четверга у деяких місцевостях починають виготовляти писанки і в Страстну Пятницю (в Боснії), в субботу (в де-яких місцевостях Кубані). Подекуди виготовляють заздалегідь, поволі (напр., Чернигівщині, Поділлю, до певної міри в Польщі). Писанки, які розписані, так званими, сорококлинцями, виготовляють звичайно в свято «Сорок мучеників».

Взагалі питання початку виготовлення писанок освітлено у нас досить добре. Ми маємо багато даних у Кульжинського, Сумцова, Ястребова, Дмитренка та инших авторів.

Торкаючися питання, хто саме виготовляє писанки, ми мусимо зазначити, що воно, на жаль, не зовсімоброблене. Правда, в гловному всі дослідувачи зходяться, а саме: так звані, воскові писанки виготовляють виключно жінки. Більше - це штучні, напр., малярські, виготовляють часто і чоловіки. Але питанняхто саме (по свойому родинному стану) виконує цю працю лишається неясним. Кульжинський подає відомости 3 ріжни х місць України про це. Він приходить до висновку, що звичайно ця справа, як поважна та серьозна, доручалася господиням (часто молодим), а коли їх в родині нема, то старшій дочці, яка веде господарство. Але в його данних зустрічаються де-які суперечности; спераючися на них можна, напр., зауважити одну цікаву рису. Молодиці і старухи виготовляють писанки переважно на Лівобережжу. На 
Правобережжу цею працею займаються виключно дівчата. Далі на Захід, напр., в Подьщі, склад більш змішаний: дівчата i молодиці. Спадає думка, чи не стоїть справа якраз навпаки, а ніж гадає Кульжинський. Чи не доручалася ця праця ранійш якраз дівчатам, а потім, 3 упадком цікавости до цього, переходила до молодиць, а в деяких місцевостях (де найменьше виготовляють писанок, напр., в Харківщині) до старух. 3'ясовання цього питання ще чекає свого дослідника.

Що торкається самих матер'ялів, які вживаються до виготовлення писанок, то ця справа освітлена досить добре. Багато авторів дають, напр.., відомости про фарби. Всі вони зходяться на тому, що вживаються звичайно фарби домашнього виробу (напр., з цибулиння, гречаної полови, сону, кори яблуні, дуба,вільхи та ин.). Де-хто з авторів (напр., Кульжинський) гадають, що вживання фабричних фарб вважається селянами за гріх. Хоч тепер, як підкреслюють де-які дослідники, з упад ком самого звичая, для виготовлення писанок подекуди вживаються і фабричні фарби.

Знаряддям малювання служить, так званий квачик, кусник заліза згорнутий в лієчку. Крім того, в де-яких місцевостях вживається зрізане пташине перо, в иньших, прив'язаний до патичка дріт від сережки (на Поділлю), або навіть стебель соломи. В Чехії вживається також гострий патичок, а в Польщі, по відомостях Кульжинського, просто шпильку. По відомостях-же Сумцова в Польщі вживається найчастіше таке-ж саме приладдя, як і на Поділлю (дріт від сережки).

В залежности від способу виготовлення розріжняються ріжні назви писанок. Найбільш проста - це крашанка: себ-то яйце пофарбоване лише в оден кольор. В иньших країнах крашанки мають иньші назви: так, на Поділлю, їх звуть галунками, в Польщі мальованками або бичками, в Чехії та Моравії - kraslice, červeati або purič - у харутан (хоч останні дві назви однакові і для писанок).

Другим типом являються, так звані, скробанки (в Гродненській губ. I на Уралі - драпанки). Це однокольорові писанки 3 білим візерунком. Далі йдуть капанки (на однокольоровому тлі ріжні плями). Найважнійшими писанками 
являються ті, що виготовлені, так званим, восковим способом. Про цей спосіб згадано у більшости праць про писанки. Тому я скажу дуже коротко про них. Спосіб виготовлення їх такий: малюються воском візерунки, потім кладуть яйце в жовту фарбу; витягнувши його звідти, знов розмальовують воском і опускають в червону, і так далі. В результаті, на якомусь певному тлі багато ріжнобарвних візерунків. Иньший варіант цього способу полягає в тому, що все яйце покривається воском, а потім, при окрасці, його по частях знимають.

Крім цих всіх писанок є ще де-які: малярські, які розмальовують ріжними фарбами маляри просто від руки без допомоги воску, i монастирські. Останні в свою чергу поділяються на вощанки, які обливають воском; часто 3 них через дірку кидається кілька горошинок i заліплюється воском - тоді вони звуться дзвонарками. Иньші, так звані, розкритки також обливаються воском і потім їх розрізають напополам; між собою обидві половинки 3’єднуються кусниками матерії.

Найбільшу літературу про ці всі категорії писанок ми знаходимо у Кульжинського.

Розглянемо тепер ужиток писанок. Обрядовий ужиток писанки пристосований головним чином, до Великодня, але він зустрічається вже й ранійш. Так, пише Сумцов, «в Бжедуковській станиці Кубанської области прикладуючися в страстну пятницю до плащаниці, кладуть коло неї червоні крашанки; або в Купянському повіті Харківщини оден з членів родини вистоює Діянія і утреню в ніч під світлу неділю 3 писанкою в кишені, яку (писанку) потім заховують на протязі року» (Сумцов: Писанки. ст. 200). Найчастіше - ці писанки служать для розговіння та христосування, а також для обміну та дарення (Сумцов, Кульжинський). На Волині писанки йдуть теж на великодні подарунки поважним особам.

Дарують писанки дівчата своїм нареченим, де-колм навпаки - парубки дівчатам (Сумцов). В Старій Сербії молодиці, що були повінчані того року, на другий день Великодня, після хрестного ходу, обходять зі свекрухами чоловіків (мужчин) і дарують їм крашанки (Ястребов). В Чехії обмін писанок вважається актом, що зміцнює приязнь (Странічек). 
На Київщині і в Галичині (як повідомляє Сумцов) на другий день Великодня, у досвіта, хлопці ходять по хатах де $є$ дорослі дівчата i, як-що знаходять їх ще неодягненими, або якщо вони ще сплять, то поливають їх водою. Щоби уникнути цеї приємности дівчатам доводиться відкупатися від них, - давати їм пару писанок. Це є пережитком старого звичая, про який ми маємо звістки ще в давні часи. Так, ще Боплан згадує в свойому описі України: «Ранком на другий день Великодня парубки юрбою ходять по вулицях і ловлять дівчат, що їм зустрічаються; ведуть полонянок до криниці і обливають їх від голови до ніг пятью-шестью ведрами води, так-що на бідненьких не лишається сухої нитки». Далі він каже, що на другий день навпаки, дівчата ловлять хлопців і поливають їх водою.

Нарівні з цим звичаєм існує в Чехії (про що свідчить Зібрт) ще, так звана, помлазка. Полягає вона в тому, що хлопці та дівчата б'ють спочатку оден одного вербою, а потім дарують оден одному писанки. Про цей звичай ми знаходимо згадки у чешських писаних пам'ятках XIV ст., а також і пізніших (напр.., в одній церковній проповіді 1610 p. Moravski ornamety). Звичай поливання водою та від дарювання писанками заховався подекуди і у поляків, і до певної міри, латишів.

Всі ці звичаї (як гадають більшість дослідників) являються пережитком весняного культу. Писанка сімволізує сонце, вода - весняні дощи. Самий обряд виявляє побажання родючости, а в переносному розумінню - сили, здоровя, радости.

Крім цих звичаїв звязаних з культом писанки, є ще агато иньших. Так, напр., ламання шкаралупи, щоб не зурочила відьма; підкладання писанки (безконечника) під вулик; «проводи», коли кладуть писанки на могилках родичів в Родительську субботу; лікування ними від ріжних хвороб, та таке инше. Взагалі, прро обрядові звичаї зв’язані з писанками знаходимо численну літературу у багатьох авторів (Кульжинський, Сумцов, Валуйко, Бінькловський, Тірелов та инші).

Дуже часто, у багатьох народів писанка вживається для великодніх ігр. Найбільш уживаються дві гри: навбитки i навкотка. Перша полягає в тому, що двох іграчів бьють одне 
яйце об друге. Друга гра така: роблють з лубка жолобок, по якому й котиться яйце. Протии нього ставлять на кон свої писанки иньші іграчи. Те з них, що буде зачеплено першою писанкою, яку котить по жолобку, віддається власникові цієї першої писанки. на Катеринославщині (як пише Сумцов) існують трохи иньші дві гри: «у сліпця» $\mathrm{i}$ «у кітця». Іграчів два. Оден ставить писанку на кон, а другий відходить в бік i закриває очи шапкою. Далі, обертається кілька разів і йде в напрямку до писанки. коли піде у вірному напрямку i спиниться коло неї, то виграє. «У кітця»- це бавляться так. Оден кладе писанку на кон, а другий, відійшовши, нахиляється і катить свою писанку так, щоби вціліти в писанку першого.

У Польщі і Росії також зустрічаються подібні гри, про що згадубть Кульжинський, Сумцов та ин. Ці гри мають, як справедливо вказує більшість дослідувачів, сімволічномитичне значіння. Катання писанки є сімволом руху сонця. Доказом митичного походження цих ігр $\epsilon$ те, що вони відбуваються й до останніх часів у латишів в честь бога сонця Усеня.

Взагалі з писанкою зв'язано дуже багато обрядових звичаїв; це відмічають більшість дослідувачів. Залишається ще додати, щодо ужитку писанки, звичай (про який каже Кульжинський) дарення писанки зі значенням. Візерунки на писанках, по словах цього дослідника, якусь свою мову. Так, напр., писанка, що розмальована, так званою, зеленою рожою, означає що та особа, яка одержала цю писанку, ще дуже молода. На жаль, більше прикладів Кульжинський не дає, зазначаючи, що йому не вдалося їх зібрати; у иньших-же дослідувачів про цей звичай нам не зустрілося жодної згадки.

Оглядаючи літератури про ужиток писанки взагалі, ми мусимо визнати, що вона досить значна. Правда, є вказівки, що звичаїв звязаних з ужитком писанки є далеко більше. Це питання ще чекає свого спеціального дослідника. Найбільшу літературу про це дають наші два українські вчені: Сумцов і Кульжинський.

\section{Орнаментація писанок}

В науковому відношенню писанки цікаві нам по свойому орнаменту. Всі дослідники згодні, що основних мотивів в 
орнаменті писанок не багато; питання лише до яких якраз основних типів можна їх звести.

У більш широкому маштабі (маштабі, так мовити, загально-орнаментальному) робить класіфікацію відомий чеський археолог dr Vankel. Він поділяє всі орнаменти (як на писанках, так і взагалі) на три головних елєменти: 1) елеєменти спільні для всіх скільки небудь культурних народів, 2) елєменти, що мають митологично-сімволічні або містичні основи і 3) пожичені у иньших народів. Звичайно, це в головних рисах і для всілякої орнаментації. Більше-ж конкретні спроби, що до класифікації мотивів наа писаночній орнаментації були зроблені иньшими дослідниками. Головних течій в цьому дослідженню є три:

1. Найбільш розповсюджене: основних мотивів є три геометричний, рослинний і тваринний (Вайссенберг, Кордуба, Тірелов та инш.). У де-кого трохи відмінна класіфікація; напрю., Глинський в «Слізаветградському Вєстніку» в своїй статті «Крашанки и писанки на Волині» дає три елєменти: геометричний, рослинний i елєменти, що неналежать до перших двох категорій. Сюди входять, напр., наслідування турецьких шалів та т. ин.

Поділи ці, по словах більш авторітетних дослідувачів, дуже невдалі.

2. Друга теорія, більш розроблена, належить проф. Сумцову. Він знаходить в писанковій орнаментації пять елєментів: геометричний (i дуже близький до нього - солярний), рослинний, тваринний, релігійний і предметно-побутовий.

3. Нарешті ще одна частина вчених тримається цілком иньшої думки. Вона класифікує писанкоий орнамент не по змісту його, а по тих основних лініях, якими ділять яйце для розмалювання, бо вони, як каже КУльжинський, надають характерний вигляд малюнку. Це думка була висловлена і у Сумцова, але побіжно; він лише відмітив цей факт, але в основу своєї класифікації їі не клав. Це ж доводила і Власта Гавелка, в своїй статті «Естетичний аналіз орнамету Великодніх яєць» в збірнику «Moravske ornamenty». Вона ділить орнаменти по лініях, які пересікають яйце напоперек або вздовж і по розетках, що містяться на кінцях писанки. Подібні-ж думки 
висловлювала і Косачева в своїй праці «Украинскій народный орнамент». Найбільш розроблену класифікацію на цій основі дає Кульжинський. Він поділяє всі писанкові орнаменти на чотири типии:

1. Коли основних ліній на поверхні писанки цілком не має.

2. На поверхні писанкиє одна чи кілька нормальних головних ліній (себ-то екватор і горізонталі, мерідіани та їх комбінації).

3. На поверхні писанки є наклонні головні лінії (одна чи кілька) окрема чи в комбінаціях з нормальними.

4. Головними лініями служать криві, себ-то криві не плискаті, а подвійної кривизни.

Теорій існує ще кілька більш дрібних. Зокрема згадаємо про теорію Болсуновського, який вважає потрібним поділяти писанки по їх назвах (Валуйко).

Не торкаючися питання, яка 3 цих гіпотез найбільш обгрунтованою, ми перейдемо до питання походження орнаменту.

Найбільш давніми з елєментів орнаментації являються, як каже Сумцов, геометричний та рослинний. Відносно походження першого є кілька теорій. Найбільш правдоподібна 3 них, на думку Сумцова, є гіпотеза, що геометричний стиль занесений індо-європейськими народами 3 їх первісної арійської батьківщини. Де-хто-ж вважає, що цей стиль пішов 3 Еллади. Французький вчений Дюмон допускає вплив фінікійський, та й взагалі азіятський, на походження і розвиток геометричного стилю орнаментації (Павлуцький: Греческія росписныя вазы. ст. 61-64). Як гадає Сумцов, первісні форми могли, завдяки своїй простоті, виникнути й самостійно у ріжних народів. Але, безперчно, треба припустити, каже він, що з часом більш розвинений геометричний орнамент, мусить впливати на иньші, і тут якраз можна відзначити вплив азіатського сходу, де геометрична орнаментація була 3 найдавніших часів надзвичайно гарна та досконала. На користь думки ро самостійне зародження геометричного орнаменту промовляє його велика розповсюдженість у більшости країн. Подібне можна сказати і про рослинний орнамент. Що до того, як 3'явився орнамент взагалі, то Маковський в статті «Кь 
исторіи народного орнамента» висуває гіпотезу, що людина брала свої сюжети просто з природи, себ-то з того, що ії̈ оточує і що легшее було змалювати (напр., сосна, сонце, вітряк і т. и.) i, стилізуючи їх, виробляла геометричний орнамент. Багато дослідників висловлювали думку, що писанкові орнаменти були в значній своїй мірі позичені 3 орнаментів иньших виробів. Ще в 1887-у році Р. Тірелов в своїй замітці «Пасхальные яйца у западнях словян» згадує, що орнаметація писанок надзвичайно подібна до орнаментів старослав'янського гончарного виробництва. В. Ястребов в своїй статті «Ньсколько словъ о писанкахъ» (Кіевская старина 1895 р) висловлює думку, що орнамент писанок українських, а також молдаванських і болгарських (до речи, цей автор гадає, що звичай уживання писанок українці і молдавани запозичили у болгар) має багато спільного з орнаментами вишивок і кілимів. Дуже цікаву теорію висуває Микола Валуйко в своїй студії «Писанки» («Сяйво» 1913 р.). він шукає споріднености орнаментації писанок з иньшою найдавнійшою українською орнаментацією. Так, на його думку, мотиви орнаменту на глиняних, полив'яних плитках князівської доби часто бувають подібні до писанкових (безконечника, скобочки, та инш.). Далі «сорокаклинці», пише Валуйко, «зустрічаються на кулеподібних скитських ковшах, що мають число дуже близьке до сорока на півкулі; зірочки, що йдуть параллельно од носика яйця-писанки, аналогічні подібним поплутаним зірочкам скитських чаш. Плетенки, ялинки, хрести, зірки візантійські і т. п., дуже схожі як до теперішніх річей, так і до тих, що були 1000 літ тому (ст. 110).

Д-р Кордуба знаходить зв’ язок між певними орнаментами галицьких писанок 3 мережковими орнаментами. Зустрічаються подібні думки і у инших авторів (Довгірд, Глинський, dr Vankel). Взагалі багато дослідувачів поділяють погляд на спорідненість орнаметації писанкової з критською орнаметацією.

Про самі назви писанок та їх значіння ми маємо досить багато згадок з ріжних авторів (Литвинова, замітки в Klosy XLIV, Горленко, Ястребов, Сумцов, кульжинський, Валуйко та инш.). 
Оскільки вони взагалі відомі, а розглядати їх занало-б занадто багато часу, то ми одсилаємо бажаючих детальнійше познайомитися 3 цим питанням до вищезгаданих авторів. Торкнемося лише питання які назви в яких країнах найчастіше уживаються (оскільки це освітлено в нашій літературі). Ми будемо вживати тут класіфікацію проф. Сумцова, поперше тому, що вона зв'язана з найбільш авторітетним іменем, а подруге, що найбільше матер'ялу по цьому питанню дає якраз Сумцов.

На Україні часто зустрічаються такі назви: 3 геометричного (і солярного) стилю - сорокаклинці, плетенка, трикветр, зоря, сояшний знак, свастика, безконечник, рідше тризуб.

3 реліг.-хрестіянського: хрестові писанки, церковки, дзвін, попівські ризи.

3 рослинного: вишневелистя, дубове листя, рожівка, ялинка.

3 тваринного: курячі лапи, півень, рак, бжола, павуки, баранячі роги, заячі вуха.

3 побутового: гребінь, калитка, граблі, сокира, мотовильце, чоботи, драбина.

В Чехо-Моравії: геометр. - плетенка, точечна орн., тризуб, трикветр, сояшний знак, пентаграмм, зоря, меандр.

3 хрест.-реліг. - хрест.

3 рослин. - листя, дзвіночки, квітка (на жаль спеціальних назв ми не знаємо).

В Росії: плетенка, сояшний знак, півень, драбина.

В Польщі: точечна орнам., зоря, пальма, сосна, заячі вуха, баранячі роги, курячі лапи, дрибина.

В Болгарії: сорокаклинці, точечна орн., півень.

В Сербіi: точечн. орнамен., гіацінт, тюлпан, яблуко, півень.

Старий звичай виготовляти писанки на прикінці XIX ст. почав сильно падати. Це підкреслюють більшість дослідників. Так Сумцов відмітив, що на Харьківщині (1890 роки) вже мало де виготовляють писанки. Тай взагалі, на Лівобережжу цей звичай майже зник. А там, де він заховався, сильно впав по своїй якости: лінії нерівні, орнаментація будь-яка, квач 
зустрічається рідко, а звичайно просто капають віск зі свічки. Так стоїть справа на Харьківщині, Катеринославщині, Полтавщині. Падає також і багацтво фарб. Починають звичайно фарбувати писанки тепер в два, maximum в три кольори. На Правобережжу, з окремо на Поділлю і на Волині, справа стоїть краще, але все-ж таки цей старий звичай занепадає. Взагалі, про його занепад свідчить багато дослідників (Сумцов, Кульжинський, Валуйко, Вайссенберг та инш.).

Правда, з одного боку ми мусимо радіти, що зникає звичай, який щей де від поганських часів і міцно тримався й вчаси хрестіянські, звичай тісно звязаний 3 ріжними забобонами та шкідливим для народньої свідомости культами. Але 3 другого боку шкода, що зникають пам'ятки народнього мистецтва і зникають без сліду, бо змальовано писанок досі порівнючи надзвичайно мало.

Розглянувши орнамент писанки, д-р Кордуба приходить до таких висновків для Галичини (а до певної міри і України).

1. Пануючим орнаментом $€$ геометричний i то простолінійний. Орнамент рослинний займає друге місце, а звірячий являє ся лиш льокальним.

2. Орнамент геометричний, рослинний, а також звіриний, коли представляє лиш поодинці части звірят, не є орігінальний i дасть ся віднайти в ріжних часах у ріжних народів. Звідкіля йшов безпосередній вплив сконстатувати поки-що неможливо, тому що наша орнаментика ще поле нерухане.

3. Орнамент звіриний, де животина змальована ціла, є орігінальний і опираєся безпосередньо на обсервації.

4. Назви поодиноких орнаментів подекуди не відповідають i походженню i вказують змагання толкувти орнамент натуралістичним.

5. Розмальовування красками поодиноких частин орнаменту $є$ примітивне і має метою лиш виріжнюванням їх, а не віддання приробньої краски.

6. Несумнівним є похожість орнаменту писаночного на мережковий, що вказує на рівнобіжний розвій їх обох i взаїмний їх вплив. Той вплив дасть ся докладнійше означити, коли орнамент мережковий буде опрацьований. 
$* * * *$

\section{Бібліографичний покажчик літератури про писанку (яку} я або сам читав, або бачив в інших авторів зміст ії).

1. Рихтер. Dissertatio de oris paschalians. Гейдельберг 1682.

2. Кобер. Dissertatio de oro paschali. Лейпціг 1690.

3. Краскій. Dissertatio de oro paschali. Франкфурт на Одері 1705.

4. Косачева. Украинскій народный орнамент. Київ 1879 р. (2 вид.)

5. Волков Ф. Отличительныя черты южно-русской народ. орнаментики. Київ 1878.

6. Литвинова. Южно-русскій народн. орнамент. В. І. Київ 1878 .

7. Kolberg Oskar. Pokucie. Krakow 1882.

8. A. P. Pisanki ukrainskie. Klosy T. XLIV. Warszawa 1887.

9. Тирелов Р. Пасхальныя яйца у западнях словян.

10. Пасхальныя яйца в странђ вендов. Всемирная Илюстрація 1887.

11. Обычай раскрашивать пасхальные яйца. Новъ. Мозаика 1887.

12. Moravské ornamenty. V Olmuzi 1888.

13. Udziela G. Piski w miescé Ropozucach i w okolicy. Tarnow 1888.

14. Ржегорж. Великоднія крашанки. Червоная Русь 1889.

15. Свитлич. Ускрашня шарена јаја. Гласник Земальского музеја. 1889.

16. Г-скій (Глінскій). Крашанки и писанки на Волыни. Елизаветград. ВҺстник 1889.

17. Dowgird i Wolskij. Pisanki, jajka malowane wie ekanocne. Warszawa 1890.

18. Dowgird Tadeusz Pisanki. Warszawa 1890.

19. Горленко. Лубенскій музей Скаржинской. Кіевская Старина 1890.

20. Zilrt. Nektere wyklady o puvodu Kraslic. 1890.

21. Molnar Victor. Husveti Tojasok (ostereier) Budapest 1890.

22. Сумцов. Писанки. Кіевская старина. 1891.

23. Дмитренко. Описанках. Кубанскія Вьдомости. 1891.

24. Schwicker Geschmückte Ostereier. Das Ausland № 21. $1891 \mathrm{p}$. 
25. Klvana. Kraslice moravské. Cesky lid. Praze 1893.

26. Крашеныя яйца. Звђзда 1894.

27. Ястребов. Матеріяли по этнографіи Новоросійского края. Одесса 1894.

28. Вейссенберг. Южно-русскія пасхальныя яйца. Zeitschrift für Ethnologic. Berlin 1894.

29. Ястребов. Пасхальныя яйца. Съвер 1895.

30. // Нъсколько слов о писанках. Кіевская старина 1895.

31. БЪньковскій. Оычаи и повЂрья приуроченыя к «Великодню». Кіев. Стар. 1895.

32. Венгреженовский. Языческій обучай в Брацлавщинъ «гонити шуляка». Кіев. Стар. 1895.

33. Кульжинській. Описаніе коллєкціи народних писанок в I-II. Москва 1899.

34. Маковскій. К исторіи народного орнамента. Искусство и художеств. промышленность. 1899.

35. Валуйко М. Писанки. Сяйво 1913 р.

С. Шамраїв [1].

Отже, підготовлений рукопис С. Шамраїва з історіографії писанкарства, що зберігається в Науковому архіві Інституту археолгії НАН України, представляє собою оригінальне дослідження яке варте уваги. Водночас, публікація розвідки 3 вивчення писанки збільшує джерельну базу з писанкарства як виду декоративно-ужиткового мистецтва.

\section{ДЖЕРЕЛА ТА ЛІТЕРАТУРА}

1. Науковий архів ІА НАН України. Ф. 9. Од. зб. № 135/в. 15 арк.

2. Ткаченко В. Рукописна спадщина Василя Кравченка про походження крашанки та писанки // НTE. 2013. № 2. C. $133-138$.

3. Ткаченко В. Писанкарство на Волині в архівній спадщині Никанора Дмитрука // Наукові записки з української історії: зб. наук. статей. Переяслав-Хмельницький, 2014. Вип. 34. C. 64-70.

4. Ткаченко В. Рукописна спадщина I. Шулікова як джерело дослідження писанкарства кінця XIX - початку XX століття // HTE. 2017. № 2. C. 96-111. 
5. Ткаченко В. Джерело 3 історіографії українського писанкарства кінця XIX - початку XX ст. // Переяславський літопис: збірник наукових статей / [ред. колегія: Коцур В. П. (голов. ред.) та ін.]. Переяслав-Хмельницький, 2018. Вип. 13. С. 120-129.

\section{REFERENCES}

1. Naukovyi arkhiv IA NAN Ukrainy [Institute of Archeology National Academy of Sciences Ukraine]. F. 9, case 135/v. 15 arcs.

2. Tkachenko, V. (2013). Rukopysna spadshyna Vasylya Kravchenka pro pokhodzhennya krashanky ta pysanky [Handwritten legacy of Vasyl Kravchenko on the origin of Easter eggs and painted eggs] Folk art and ethnology, 2, 133-138 [in Ukrainian].

3. Tkachenko, V. (2014). Pysankarstvo na Volyni v arkhivnii spadshhyni Nykanora Dmytruka [Easter eggs in Volyn in the archival heritage of Nicanor Dmitruk] Scientific Notes on Ukrainian History: Collection scientific articles, Pereyaslav-Khmelnytsky, 34, 64-70 [in Ukrainian].

4. Tkachenko, V. (2017). Rukopysna spadshchyna I. Shulikova yak dzherelo doslidzhennia pysankarstva kintsia XIX - pochatku $X X$ stolittia [Manuscript inheritance of I. Shulikov as a source of Easter eggs study of the end of XIX - beginning of the XX century] Folk art and ethnology, 2, 96-111 [in Ukrainian].

5. Tkachenko, V. (2018). Dzherelo z istoriohrafii ukrainskoho pysankarstva kintsia XIX-pochatku XX st. [A source from the historiography of Ukrainian Easter eggs of the late XIX - early XX centuries] Pereyaslav Chronicle: Collection scientific articles, Pereyaslav-Khmelnytsky, 13, 120-129 [in Ukrainian].

\section{АНОТАЦІЯ}

Автором оприлюднюються матеріали з історіографіi українського писанкарства кінця ХІХ - 20-х рp. XX cm. підготовлені С. Шамраєвим. Дослідник намагається проаналізувати найбільш відомі видання М. Сумцуова, С. Кулжсинського, М. Кордуби, В. Ястребова, М. Валуйка, И. Беньковського, Р. Тірелова та інших, щзо надруковані в Украӥні та за ї̈ межами. На початку роботи автор зазначає, 
щзо ще до 20-х років XX ст. виявлена література про писанки складається з невеликих заміток, які згадують про існування писанок та відзначають потребу їх дослідження. Для їх огляду ним використовувався "хронологічно-бібліографічний метод» y поєднанні з намаганням показати як підходили до висвітлення того чи іншого питання різні дослідники писанок.

С. Шамраїв розпочав своє дослідження літератури 3 авторів, які висвітлювали походження писанок; вказує, яких поглядів вони дотримувалися та зазначає, щзо загалом існує два: перший, який більш науково доведений $i$ пов'язаний 3 язичницьким культом яйия, а другий з християнством, яке використало символіку у своїх інтересах.

Автор розглянув і питання самого виготовлення писанок, коли це робили, в який час, які інструменти, фарби використовували, які існують технології оздоблення тощуо.

Не оминув він й питання висвітлення дослідниками орнаментації писанок, їх походження, зокрема $і$ класифікації, наводячи запропоновані розробки з изього питання Венкеля, Сумцова, Кордуби, Кульжинського та інших учених. Зазначаючи, шуо загалом усі розробки можна розділити на три напрямки.

Метою статті є публікація архівного першоджерела та ознайомлення із ним широкого загалу науковців.

У ході роботи було використано методи пошуку, систематизації, аналізу отриманих даних.

Опрацюювання Наукового архіву Інституту археологіi НАН України та інших джерел, дало можливість автору констатувати, щзо проблематика історіографії писанкарства розроблялася у 20-х рр. ХХ ст., різними дослідниками, є досить різноплановою, потребує належного опрацювання і введення до наукового обігу.

Ключові слова: С. Шамраїв, писанка, архів, джерела, історіографія, вивчення.

\section{АННОТАЦИЯ}

Автором публикуются материаль по историографии украинских писанок конца XIX-20-х г2. XX в., подготовлень С. Шамраевыл. Исследователь пытается проанализировать наиболее известные издания М. Сумияова, С. Кулэниского, 
М. Кордубы,, В. Ястребова, М. Валуйко, И. Беньковской, Р. Тирелова и других, опубликованные в Украине и за ее пределами. В начале работы автор отмечает, что еще до 20-х годов обнаруженая литература о писанках состоит из небольших заметок, которые вспоминают о существовании писанок и отмечают необходимость их исследования. Для их осмотра ним использовался «хронологически библиографический метод» в сочетании с попьткой показать как подходили к освещеению того или иного вопроса разные исследователи писанок.

С. Шамраев начал свое исследование литературы из авторов освещцавших происхождения писанок; указывает каких взглядов они придержсивались и отмечает, что в целом существует два: первый, более научно доказанный и связанный с языческим культом яйца, а второй с христианством, которое использовало символику в своих интересах.

Автор рассмотрел и вопрос самого изготовления писанок, когда это делали, в какое время, какие инструменты, краски использовали, которые существуют технологии отделки и т.д.

Не обошел он и вопрос освещения исследователями орнаментации писанок, их происхождения, в том числе и классификации, приводя предложенные разработки по этому вопросу Венкеля, Сумцова, Кордуби, Кульжинского и других ученых. Отмечая, что в челом все разработки можно разделить на три направления.

Целью статьи является публикачия архивного первочсточника и ознакомления с ним широкой общественности ученых.

В ходе работы были использованы методы поиска, систематизации, анализа полученных данных.

Обработка Научного архива Института археологии НАН Украинь и других источников, позволила автору констатировать, что проблематика историографии писанок разрабатывалась в 20-х г2. ХХ в. различными исследователями, является достаточно разноплановой, требует надлежащей проработки и введение в научный оборот.

Ключевые слова: С. Шамраев, писанка, архив, источники, историография изучения. 